\title{
Effect of Different Fortifications of Panchgavya with Nigella sativa and Asparagus racemosus on Haematological Parameters in Poultry
}

\author{
Kamal Kishor*, Y. P. Sahni, R. P. Singh, N. S. Meena and Rituraj Kewat \\ Department of Veterinary Pharmacology and Toxicology, College of Veterinary Science and \\ Animal Husbandry, Nanaji Deshmukh Veterinary Science University, Jabalpur, Madhya \\ Pradesh, India \\ *Corresponding author
}

\section{A B S T R A C T}

K e y w or d s
Panchgavya,
Nigella sativa,
Asparagus
racemosus,
Narmada Nidhi and
Haematological
parameters

\begin{abstract}
In world-wide excessive use of antibiotics are in poultry industry for the prevention of diseases and increase productivity. The use of antibiotics has been also considered as hazardous with the unavoidable spread of bacterial resistance and cross resistance. In general, haematological examination is performed for several reasons as a screening procedure to assess general health. Panchgavya has been claimed to be useful against several body ailments in rats. The herb Nigella sativa is known as "Kalonji". Nigella sativa has been extensively studied for its biological activities and therapeutic potential and it possess wide spectrum of activities. Asparagus racemosus are called as "Shatavari" or "Queen of herbs". It is traditionally used against some physiological disturbances in body system. The study was conducted on 96 healthy Narmada Nidhi day-old chicks, divided into 8 groups consisting 12 chicks with 2 replicates each. The diet of birds was supplemented with Panchgavya, Nigella sativa, Asparagus racemosus and their combinations daily for 56 consecutive days. It may be concluded that the supplementation of Panchgavya significant increased Total Erythrocyte Count and haemoglobin content at day 42 of the experiment.
\end{abstract}

\section{Introduction}

The uses of antibiotics as growth promoters in poultry are facing serious criticism now days. If we focus on present scenario than, due to excessive use of antibiotics in the livestock's, the multi-drug resistance has been arises. The utilization of growth promoters of natural origin become of an area of interest (Wray and Davies, 2000). In poultry industry antibiotics have been used widely in world- wide in order to prevent poultry disease and overall increase production.

The use of antibiotics has been considered as hazardous with the unavoidable spread of bacterial resistance and cross resistance (Andremont, 2000). Lots of feed additives have been proven as growth promoters to avoid the massive use of antibiotics or at least decrease or minimize their inclusion in feeds, while maintaining a very efficient animal 
production to get safe edible food products (Islam et al., 2005; Gomez et al., 2012).

In general, blood examination is performed for several reasons as a screening procedure to assess general health of body system (Jain, 1993). The haematological estimation is also important to clinico-pathological diagnosis such as parasitism, bacterial septicemia, traumatic injury, nutritional deficiencies and physiological change to some tissue or organ of the body. For prevention of abnormalities in birds requires an understanding of how a disease changes the functioning of haematology, biochemical and electrolyte of the body system. Due to the clinical signs of illness in birds some times are very minute and occurs very short duration of period, clinical chemistry is necessary to evaluate cellular changes (Ritchie et al., 1994). In Ayurveda mentioned Panchgavya is one such formulation, which are prepared with five components derived from cow viz. milk, curd, ghee, urine and dung and can be used as growth promoters in animals (Dhama et al., 2005). Panchgavya has been mention to be useful as hepatoprotective, anti-inflammatory, antipyretic and immune-stimulant in rats. The herb Nigella sativa is known as "Kalonji". Nigella sativa has been extensively studied for its biological activities and therapeutic potential and it possess wide spectrum of therapeutic activities.

Most of the therapeutic properties of this plant are due to the presence of pharmacological active principal thymoquinone, thymol and carvacol (Sarkar et al., 2015). The family aspragaceae contain a medicinal herb Asparagus racemosus which is called as "Shatavari" or "Queen of herbs". Asparagus racemosus are traditionally used against topical wound or skin infection, diarrhoea, dysentery and various parasitic infections. This plant is also recommended in Ayurveda for prevention and treatment of gastric ulcers, dyspepsia and as a galactogogue. Some ayurvedic practitioners have been successfully employed Asparagus racemosus as anti-inflammatory, hepatoprotective, nervous disorder and certain infectious diseases (Sinha and Biswas 2011). The Panchgavya formulation and medicinal herbs Nigella sativa and Asparagus racemosus may serve as alternatives of antibiotics in poultry due to their therapeutic efficacy and minimum health hazards.

\section{Materials and Methods}

\section{Plant material}

Roots of Asparagus racemosus and seeds of Nigella sativa were procured from the Department of Aromatic and Medicinal Plants, Agriculture College, Jawaharlal Nehru Krishi Vishwavidyalaya, Jabalpur, Madhya Pradesh. Roots of Asparagus racemosus and seeds of Nigella sativa were dried, crushed and used for supplementation of diet in chicks/birds.

\section{Preparation of panchgavya}

The Panchgavya was prepared by using fresh Cow dung (5 parts), urine (3 parts), milk (2 parts), curd (2 parts) and ghee (1 part) obtained from indigenous cow of Livestock Farm Adhartal, Jabalpur along with other ingredients viz. sugarcane juice (3 parts), tender coconut juice (3 parts), ripened banana (12 numbers) and toddy (2 parts) as per the method described by Natarajan (2003). The fresh Cow dung was thoroughly mixed with ghee in a wide mouth mud pot and kept for three days. The above mixture was thoroughly mixed once daily. On the fourth day, other ingredients were added to the mud pot and mixed properly. The pot was placed in shade and mixed thoroughly twice a day for 30 days to obtain Panchgavya. After 30days the Panchgavya was ready for experimental use. 


\section{Experimental birds}

The study was conducted on a total of 96 healthy Narmada Nidhi day-old dual purpose coloured chicks were procured from All India Co-ordinated Research Project (AICRP) on poultry breeding Farm Adhartal, Jabalpur (M.P) and maintained in deep litter system at project poultry Live Stock Farm (LSF) Adhartal, Jabalpur (M.P). All the experimental birds were kept under constant observations during the entire period of experiment (Table 2).

\section{Brooding and rearing of chicks}

Initially the poultry shed was disinfected with the commercially available disinfectants followed by the cleaning of shed. The complete house was whitewashed and properly fumigated 4-5 days before the start of experiment. The chicks pens were prepared accordingly as per the design of experiment in order to provide separate space for the each replicated groups. The feeders and waterers were cleaned thoroughly and sun dried. Rice husk and saw dust was used as bedding material. During the period of first 3-4 days newspaper were spread over litter material. Every morning and evening the linear chicks feeders were filled with the weighed quantity of experimental diet and residual feed was collected and weighed at end of week. Fresh and clean water was offered during the entire experiment. Uniform conditions of housing, brooding and watering were maintained in all the groups except dietary treatments. A total 96 chicks was randomly divided into eight groups with respective two replicates and placed in pans as per experimental design.

\section{Basal diet of experimental birds}

The basal diets consist of 20 per cent $\mathrm{CP}$ and $2800 \mathrm{kcal}$. ME $/ \mathrm{kg}$ of diet was provided to Narmada Nidhi birds (Table 1).

\section{Collection of blood}

Two $\mathrm{ml}$ fresh blood was collected aseptically from the wing vein of poultry on day 42 and 56 in ethylene diamine tetra-acetic acid (EDTA) containing anticoagulant tubes for determination of haematological profile. EDTA blood was kept at $4^{\circ} \mathrm{C}$ till further analysis (Miraghaee et al., 2011). Natt Herriek solution was used as dilution of erythrocytes and leucocytes recommended by Natt and Herriek (1952) with slight modifications.

\section{The following haematological parameters} were studied

Total Erythrocyte Count (TEC) $\left(\times 10^{6} / \mu 1\right)$, Total Leucocyte Count (TLC) $\left(\times 10^{3} / \mu \mathrm{l}\right)$, Haemoglobin (Hb) (g/dl), Packed Cell Volume (PCV) (\%) and Mean Corpuscular Volume (MCV) (fl)

\section{Total erythrocytes}

The red blood cells were counted according to standard procedure Sohalm et al., (1975) and the number of cells multiplied by 1000 due to dilution of blood 1 in 200.

\section{Total leucocytes}

The counting of leucocytes was done as per the method described by Natt and Herriek (1952). The leucocytes in the entire central $1 \mathrm{~mm}$ square (400 small squares) were counted. Total counted leucocytes were multiplied by 1000 .

\section{Haemoglobin estimation}

Estimation of haemoglobin was done by Sahli's haemoglobinometer. The blood was sucked in pipette up to the calibrated mark. It was poured in to a graduated tube containing $\mathrm{N} / 10 \mathrm{HCL}$ up to 2 marks. Added N/10 HCL 
drop by drop until the colour of tube matched with the standard colour. The end point reading was noted (Sohalm et al., (1975).

\section{Packed Cell Volume (PCV)}

The blood was drawn in to $75 \mathrm{~mm}$ tube by capillary action to three fourth of its length. Capillary was wiped free of blood outside. The blood was permitted to move few millimeters towards dry end. Index finger was placed over the wet end to stop further movement of blood. The dry end of tube was inserted in to the sealing material. (Seal Ease) to put it. The capillary tube was placed in to microhaematocrit centrifuge (Remi) with sealed end pointing outside. The number of the slot in which the tube was placed was noted. Then sample was centrifuged for 5 minutes at $12,000 \mathrm{rpm}$. Tubes were then removed and note the reading of packed cell volume was recorded.

\section{Mean Corpuscular Volume (MCV) in femtoliters (fl)}

The mean corpuscular volume (percentage) was calculated with the help of packed cell volume and number of erythrocytes (millions/ $\mu 1$ ).

$$
\mathrm{MCV}=\frac{\mathrm{PCV} \times 10}{\mathrm{TEC}}
$$

\section{Statistical analysis}

The data were analyzed using two way analysis of variance and difference among treatments was compared by Duncan's Multiple Range Test (DMRT) and this standard statistical design outlined by Snedecor and Cochran (1994).

\section{Results and Discussion}

The result of dietary supplementation of Panchgavya, Nigella sativa, Asparagus racemosus and their combinations on hematological parameters including Total Erythrocytes Counts (TEC), Total Leucocyte Counts (TLC), haemoglobin and Mean Corpuscular Volume (MCV) have been shown in table 3 to 7 .

The results of hematological analysis revealed that Panchgavya, Nigella sativa and Asparagus racemosus significantly increased Total Erythrocyte Count, Packed Cell Volume and haemoglobin level on day 42 and 56 of treatment. No change was observed in Total Leucocyte Count and Mean Corpuscular Volume in birds supplemented with different treatments. Panchgavya @ 7.5 per cent exhibited maximum increase in Total Erythrocyte Count and haemoglobin level in birds on day 42 and 56.

Table.1 Composition of basal diet per $100 \mathrm{~kg}$

\begin{tabular}{|c|l|c|}
\hline S. No. & \multicolumn{1}{|c|}{ Ingredients } & Quantity per $\mathbf{1 0 0} \mathbf{~ k g}$ basal diet \\
\hline $\mathbf{1 .}$ & Maize & $62 \mathrm{~kg}$ \\
\hline $\mathbf{2 .}$ & Rice polish & $02 \mathrm{~kg}$ \\
\hline $\mathbf{3 .}$ & Soya bean & $31 \mathrm{~kg}$ \\
\hline $\mathbf{4 .}$ & Lime stone powder & $02 \mathrm{~kg}$ \\
\hline $\mathbf{5 .}$ & Di-calcium phosphate & $300 \mathrm{~g}$ \\
\hline $\mathbf{6 .}$ & Vitamin + Mineral mixture & $2.5 \mathrm{~kg}$ \\
\hline $\mathbf{7 .}$ & Salt & $200 \mathrm{~g}$ \\
\hline & & $100 \mathrm{~kg}$ \\
\hline & Total & \\
\hline
\end{tabular}


Table.2 Design of experiment

\begin{tabular}{|c|c|c|c|c|c|}
\hline S.No. & Group & Treatment with basal diet & Replicate & $\begin{array}{l}\text { No. of birds } \\
\text { per replicate }\end{array}$ & $\begin{array}{l}\text { No. of birds } \\
\text { per } \\
\text { treatment }\end{array}$ \\
\hline 1 & $\mathrm{~T} 1$ & Control & $\begin{array}{l}\text { R1 } \\
\text { R2 }\end{array}$ & $\begin{array}{l}06 \\
06\end{array}$ & 12 \\
\hline 2 & $\mathrm{~T} 2$ & Panchgavya@7.5 per cent & $\begin{array}{l}\mathrm{R} 1 \\
\mathrm{R} 2\end{array}$ & $\begin{array}{l}06 \\
06\end{array}$ & 12 \\
\hline 3 & T3 & Nigellasativa@1 per cent & $\begin{array}{l}\text { R1 } \\
\text { R2 }\end{array}$ & $\begin{array}{l}06 \\
06\end{array}$ & 12 \\
\hline 4 & $\mathrm{~T} 4$ & $\begin{array}{l}\text { Asparagus racemosus@1 per } \\
\text { cent }\end{array}$ & $\begin{array}{l}\mathrm{R} 1 \\
\mathrm{R} 2\end{array}$ & $\begin{array}{l}06 \\
06\end{array}$ & 12 \\
\hline 5 & T5 & $\begin{array}{l}\text { Panchgavya@ } 7.5 \text { per cent and } \\
\text { Nigellasativa@1 per cent }\end{array}$ & $\begin{array}{l}\text { R1 } \\
\text { R2 }\end{array}$ & $\begin{array}{l}06 \\
06\end{array}$ & 12 \\
\hline 6 & T6 & $\begin{array}{l}\text { Panchgavya@ } 9.5 \text { per cent and } \\
\text { Asparagus racemosus @ } 1 \text { per } \\
\text { cent }\end{array}$ & $\begin{array}{l}\mathrm{R} 1 \\
\mathrm{R} 2\end{array}$ & $\begin{array}{l}06 \\
06\end{array}$ & 12 \\
\hline 7 & $\mathrm{~T} 7$ & $\begin{array}{l}\text { Nigella sativa and Asparagus } \\
\text { racemosus@1 per cent }\end{array}$ & $\begin{array}{l}\text { R1 } \\
\text { R2 }\end{array}$ & $\begin{array}{l}06 \\
06\end{array}$ & 12 \\
\hline 8 & $\mathrm{~T} 8$ & $\begin{array}{l}\text { Panchgavya@ } 7.5 \text { per cent, } \\
\text { Nigella sativa and Asparagus } \\
\text { racemosus@1 per cent }\end{array}$ & $\begin{array}{l}\mathrm{R} 1 \\
\mathrm{R} 2\end{array}$ & $\begin{array}{l}06 \\
06\end{array}$ & 12 \\
\hline
\end{tabular}

Table.3 Effect of dietary supplementation of Panchgavya, Nigella sativa, Asparagus racemosus and their combinations on total erythrocyte count in birds

\begin{tabular}{|c|c|c|c|}
\hline Group & Treatment with basal diet & $\begin{array}{l}\text { Day } 42 \\
\left(10^{6} / \mu \mathrm{l}\right)\end{array}$ & $\begin{array}{l}\text { Day } 56 \\
\left(10^{6} / \mu \mathrm{l}\right)\end{array}$ \\
\hline T1 & Control & $4.13^{b} \pm 0.19$ & $5.30^{\mathrm{a}} \pm 0.21$ \\
\hline $\mathbf{T} 2$ & Panchgavya@7.5 of per cent & $5.58^{\mathrm{a}} \pm 0.28$ & $5.85^{\mathrm{a}} \pm 0.26$ \\
\hline T3 & Nigellasativa@1 of per cent & $4.90^{\mathrm{a}} \pm 0.19$ & $5.35^{\mathrm{a}} \pm 0.14$ \\
\hline T4 & Asparagus racemosus@1 of percent & $4.80^{\mathrm{a}} \pm 0.28$ & $5.14^{\mathrm{a}} \pm 0.26$ \\
\hline T5 & $\begin{array}{l}\text { Panchgavya@7.5 and Nigella sativa } \\
\text { @1 per cent }\end{array}$ & $5.44^{\mathrm{a}} \pm 0.18$ & $5.18^{\mathrm{a}} \pm 0.16$ \\
\hline T6 & $\begin{array}{l}\text { Panchgavya@ } 9.5 \text { and Asparagus } \\
\text { racemosus@1 per cent }\end{array}$ & $4.65^{\mathrm{a}} \pm 0.37$ & $4.48^{\mathrm{a}} \pm 0.26$ \\
\hline T7 & $\begin{array}{l}\text { Nigella sativa and Asparagus } \\
\text { racemosus@1 percent }\end{array}$ & $5.14^{\mathrm{a}} \pm 0.13$ & $5.20^{\mathrm{a}} \pm 0.30$ \\
\hline T8 & $\begin{array}{l}\text { Panchgavya@7.5, Nigella sativa and } \\
\text { Asparagus racemosus @ } 1 \text { per cent }\end{array}$ & $4.90^{\mathrm{a}} \pm 0.29$ & $5.15^{\mathrm{a}} \pm 0.31$ \\
\hline
\end{tabular}

Mean values in the same column and same row bearing different superscripts differ significantly $\left({ }^{\mathrm{a}, \mathrm{b}}\right.$, $\mathrm{p} \leq 0.05$ ) 
Table.4 Effect of dietary supplementation of Panchgavya, Nigella sativa, Asparagus racemosus and their combinations on Total Leucocyte Count in birds

\begin{tabular}{|c|c|c|c|}
\hline $\begin{array}{c}\text { Grou } \\
\text { p }\end{array}$ & Treatment with basal diet & $\begin{array}{l}\text { Day } 42 \\
\left(10^{3} / \mu \mathrm{l}\right)\end{array}$ & $\begin{array}{l}\text { Day } 56 \\
\left(10^{3} / \mu \mathrm{l}\right)\end{array}$ \\
\hline T1 & Control & $24.08^{\mathrm{a}} \pm 1.51$ & $27.17^{\mathrm{a}} \pm 1.04$ \\
\hline $\mathbf{T 2}$ & Panchgavya @ 7.5 per cent & $26.83^{\mathrm{a}} \pm 1.46$ & $27.92^{\mathrm{a}} \pm 1.14$ \\
\hline T3 & Nigellasativa@1 per cent & $20.50^{\mathrm{b}} \pm 1.37$ & $24.58^{\mathrm{a}} \pm 1.30$ \\
\hline T4 & Asparagus racemosus @ 1 percent & $21.83^{\mathrm{a}} \pm 1.57$ & $24.42^{\mathrm{a}} \pm 1.60$ \\
\hline T5 & $\begin{array}{c}\text { Panchgavya @ } 7.5 \text { and Nigella sativa } \\
\text { @ } 1 \text { per cent }\end{array}$ & $24.00^{\mathrm{a}} \pm 1.41$ & $24.08^{\mathrm{a}} \pm 1.87$ \\
\hline T6 & $\begin{array}{c}\text { Panchgavya@7.5 and Asparagus } \\
\text { racemosus@1 per cent }\end{array}$ & $19.92^{\mathrm{a}} \pm 1.43$ & $22.50^{\mathrm{a}} \pm 1.55$ \\
\hline T7 & $\begin{array}{l}\text { Nigella sativa and Asparagus } \\
\text { racemosus @ } 1 \text { per cent }\end{array}$ & $24.00^{\mathrm{a}} \pm 1.77$ & $23.83^{\mathrm{a}} \pm 1.81$ \\
\hline T8 & $\begin{array}{c}\text { Panchgavya @ 7.5, Nigella sativa and } \\
\text { Asparagus racemosus @ } 1 \text { per cent }\end{array}$ & $25.25^{\mathrm{a}} \pm 1.26$ & $23.83^{\mathrm{a}} \pm 1.49$ \\
\hline
\end{tabular}

Mean values in the same column and same row bearing same superscripts differ non- significantly

Table.5 Effect of dietary supplementation of Panchgavya, Nigella sativa, Asparagus racemosus and their combinations on haemoglobin in birds

\begin{tabular}{|c|l|c|c|}
\hline $\begin{array}{c}\text { Grou } \\
\mathbf{p}\end{array}$ & \multicolumn{1}{|c|}{ Treatment with basal diet } & $\begin{array}{c}\text { Day 42 } \\
(\mathbf{g} / \mathbf{d l})\end{array}$ & $\begin{array}{c}\text { Day 56 } \\
(\mathbf{g} / \mathbf{d l})\end{array}$ \\
\hline $\mathbf{T 1}$ & Control & $08.60^{\mathrm{b}} \pm 0.43$ & $10.86^{\mathrm{a}} \pm 0.47$ \\
\hline $\mathbf{T 2}$ & Panchgavya @ 7.5 per cent & $11.70^{\mathrm{a}} \pm 0.62$ & $12.18^{\mathrm{a}} \pm 0.65$ \\
\hline T3 & Nigella sativa @ 1 per cent & $09.23^{\mathrm{a}} \pm 0.49$ & $10.25^{\mathrm{a}} \pm 0.37$ \\
\hline T4 & Asparagus racemosus @ 1 per cent & $09.96^{\mathrm{a}} \pm 0.70$ & $10.46^{\mathrm{a}} \pm 0.63$ \\
\hline T5 & $\begin{array}{l}\text { Panchgavya @ 7.5 and Nigella sativa } \\
\text { @ 1 per cent }\end{array}$ & $11.18^{\mathrm{a}} \pm 0.43$ & $10.71^{\mathrm{a}} \pm 0.32$ \\
\hline T6 & $\begin{array}{l}\text { Panchgavya @ 7.5 and Asparagus } \\
\text { racemosus @ 1 per cent }\end{array}$ & $09.33^{\mathrm{a}} \pm 0.72$ & $09.10^{\mathrm{a}} \pm 0.49$ \\
\hline T7 & $\begin{array}{l}\text { Nigella sativa and Asparagus } \\
\text { racemosus @ 1 per cent }\end{array}$ & $10.36^{\mathrm{a}} \pm 0.20$ & $10.78^{\mathrm{a}} \pm 0.45$ \\
\hline T8 & $\begin{array}{l}\text { Panchgavya @ 7.5, Nigella sativa and } \\
\text { Asparagus racemosus @ 1 per cent }\end{array}$ & $10.07^{\mathrm{a}} \pm 0.56$ & $10.86^{\mathrm{a} \pm 0.63}$ \\
\hline
\end{tabular}

Mean values in the same column and same row bearing different superscripts differ significantly ${ }^{\mathrm{a}, \mathrm{b},}, \mathrm{p} \leq 0.05$ ) 
Table.6 Effect of dietary supplementation of Panchgavya, Nigella sativa, Asparagus racemosus and their combinations on Packed Cell Volume (PCV) in birds

\begin{tabular}{|c|c|c|c|}
\hline $\begin{array}{c}\text { Grou } \\
\text { p }\end{array}$ & Treatment with basal diet & $\begin{array}{c}\text { Day 42 } \\
\text { (per cent) }\end{array}$ & $\begin{array}{c}\text { Day 56 } \\
\text { (per cent) }\end{array}$ \\
\hline T1 & Control & $25.50^{\mathrm{b}} \pm 1.31$ & $33.33^{\mathrm{a}} \pm 1.34$ \\
\hline T2 & Panchgavya @ 7.5 per cent & $35.67^{\mathrm{a}} \pm 1.83$ & $37.17^{\mathrm{a}} \pm 1.83$ \\
\hline T3 & Nigella sativa @ 1 per cent & $28.92^{\mathrm{a}} \pm 1.39$ & $31.83^{\mathrm{a}} \pm 1.07$ \\
\hline T4 & Asparagus racemosus @ 1 per cent & $30.00^{\mathrm{a}} \pm 2.19$ & $32.42^{\mathrm{a}} \pm 1.79$ \\
\hline T5 & $\begin{array}{c}\text { Panchgavya @ 7.5 and Nigella sativa } \\
\text { @ 1 per cent }\end{array}$ & $33.42^{\mathrm{a}} \pm 1.27$ & $32.33^{\mathrm{a}} \pm 1.30$ \\
\hline T6 & $\begin{array}{c}\text { Panchgavya @ 7.5 and Asparagus } \\
\text { racemosus @ 1 per cent }\end{array}$ & $28.25^{\mathrm{a}} \pm 2.30$ & $27.08^{\mathrm{a}} \pm 1.58$ \\
\hline T7 & $\begin{array}{c}\text { Nigella sativa and Asparagus } \\
\text { racemosus @ 1 per cent }\end{array}$ & $31.25^{\mathrm{a}} \pm 0.90$ & $32.25^{\mathrm{a}} \pm 1.52$ \\
\hline T8 & $\begin{array}{c}\text { Panchgavya @ 7.5, Nigella sativa and } \\
\text { Asparagus racemosus @ 1 per cent }\end{array}$ & $31.17^{\mathrm{a}} \pm 1.94$ & $31.50^{\mathrm{a}} \pm 1.73$ \\
\hline
\end{tabular}

Mean values in the same column and same row bearing different superscripts differ significantly (a,b, $\mathrm{p} \leq 0.05)$

Table.7 Effect of dietary supplementation of Panchgavya, Nigella sativa, Asparagus racemosus and their combinations on Mean Corpuscular Volume (MCV) in birds

\begin{tabular}{|c|l|c|c|}
\hline Group & \multicolumn{1}{|c|}{ Treatment (in basal diet) } & $\begin{array}{c}\text { Day 42 } \\
\text { (fl) }\end{array}$ & $\begin{array}{c}\text { Day 56 } \\
\text { (fl) }\end{array}$ \\
\hline T1 & Control & $61.60^{\mathrm{a}} \pm 0.62$ & $62.98^{\mathrm{a}} \pm 1.05$ \\
\hline T2 & Panchgavya @ 7.5 per cent & $63.99^{\mathrm{a}} \pm 0.87$ & $63.39^{\mathrm{a}} \pm 1.08$ \\
\hline T3 & Nigella sativa @ 1 per cent & $58.91^{\mathrm{a}} \pm 0.58$ & $59.40^{\mathrm{a}} \pm 0.51$ \\
\hline T4 & Asparagus racemosus @ 1 per cent & $62.05^{\mathrm{a}} \pm 1.94$ & $63.05^{\mathrm{a}} \pm 1.07$ \\
\hline T5 & $\begin{array}{l}\text { Panchgavya @ 7.5 and Nigella sativa @ } \\
\text { 1 per cent }\end{array}$ & $61.38^{\mathrm{a}} \pm 0.97$ & $62.33^{\mathrm{a}} \pm 1.44$ \\
\hline T6 & $\begin{array}{l}\text { Panchgavya @ 7.5 and Asparagus } \\
\text { racemosus @ 1 per cent }\end{array}$ & $60.61^{\mathrm{a}} \pm 0.40$ & $60.42^{\mathrm{a}} \pm 0.40$ \\
\hline T7 & $\begin{array}{l}\text { Nigella sativa and Asparagus racemosus } \\
\text { @ 1 per cent }\end{array}$ & $60.55^{\mathrm{a}} \pm 0.64$ & $66.73^{\mathrm{a}} \pm 4.30$ \\
\hline T8 & $\begin{array}{l}\text { Panchgavya @ 7.5, Nigella sativa and } \\
\text { Asparagus racemosus @ 1 per cent }\end{array}$ & $63.64^{\mathrm{a}} \pm 1.16$ & $61.59^{\mathrm{a}} \pm 0.94$ \\
\hline
\end{tabular}

Mean values in the same column and same row bearing same superscripts differ non- significantly ${ }^{\mathrm{a}, \mathrm{b}}$, $\mathrm{p} \leq 0.05)$

The considerable levels of haemoglobin and Total Erythrocyte Count were also increased significantly with Nigella sativa and Asparagus racemosus. Haemoglobin level was observed significantly higher in Panchgavya, Nigella sativa and Asparagus racemosus treated groups, which is in closed accordance with the findings of Kant et al., (2014). They further observed that supplementation of 1 per cent Asparagus racemosus increased haemoglobin level in broilers. 
In Ayurveda, Panchgavya has been claimed to improve hematological parameters including Total Erythrocyte Count and haemoglobin counts. The similar report has been cited by Mathivanan et al., (2007) who also observed significant increase in Total Erythrocyte Count and haemoglobin level in broilers supplemented with Panchgavya @ 7.5 per cent in ration. In the present study, no significant alteration in level of Total Leucocyte Count and Mean Corpuscular Volume were observed which is similar to the report of Gilani at el. (2018) who also found no significant change in Mean Corpuscular Volume and Total Leucocyte Count in broiler chicken.

The improved hematological impact of Panchgavya and indigenous herbs observed in the present study may be attributed to ingredients like folic acid, iron and vitamin $\mathrm{C}$ which are blood forming factors that stimulate blood production in the bone marrow. The positive hematological impact of Nigella sativa on the profile may be associated with its bioactive components particularly Thymoquinone which has been reported to possess antioxidant activity (Arslan et al., 2005).

In conclusions the supplementation of Panchgavya significant increased Total Erythrocyte Count and haemoglobin content at day 42 of the experiment. The dietary supplementation of Panchgavya, Nigella sativa, Asparagus racemosus and their combinations are improved overall haematological parameters in birds.

\section{References}

Andremont, A. Consequences antibiotic therapy to the intestinal ecosystem. Annales Françaises d'Anes- thésie et de Réanimation. 2000; 19: 395-402.

Arslan, S.O., Gelir, E., Armutcu, F., Coskun,
O., Gurel, A., Sayan, H. and Celik, I.L. The protective effect of Thymoquinone on ethanol-induced acute gastric damage in the rat. Nutrition Research. 2005; 25: 673-680.

Dhama, K., Chauhan, R.S. and Lokesh, S. Anticancer activity of cow urine: current status and future directions. International Journal of Cow Science. 2005; 1: 1-25.

Gilani, S.M.H., Zehra, S., Galani, S. and Ashraf, A. Effect of natural growth promoters on immunity and biochemical and haematological parameters of broiler chickens. Tropical Journal of Pharmaceutical Research. 2018; 17(4): 627-633.

Gomez, S., Angeles, M. L., Mojica, M. C. and Jalukar, S. Combination of an enzymatically hydrolyzed yeast and yeast hematological culture with a directfed microbial in the feeds of broiler chickens. Asian Australian Journal of Animal Science. 2012; 25:665-6

Islam, K.M., Schuhmacher, S.A. and Gropp, M.J. Humic acid substances in animal agriculture. Pakistan Journal of Nutrition. 2005; 4: 126-134.

Jain, N. C. Essential of Veterinary Hematology, Lea\& Febiger, Philadelphia. 1993.

Kant, S., Ali, N., Chandra, G. and Siddique, R.A. Effect of shatavari and vitamin $E$ on hemato-biochemical profile of broilers during the winter season. Veterinary World. 2014; 7(11): 948951.

Mathivanan, R., Edvin, S.C., Amutha, R. and Viswanathan, K. Panchgavya and Andrographis paniculata as alternatives to antibiotic growth promoter on broiler production and carcass characteristics. International Journal of Poultry Science. 2007; 5: 1144-1150.

Miraghaee, S.S., Heidary, B., Almasi, H., 
Shabani, A., Elahi, M. and Nia, M.H.M. The effect of Nigella sativa powder (black seed) and Echinacea purpuria (L.) Moench extract on performance, some blood biochemical and haematological parameters in broiler chickens. African Journal of Biotechnology. 2011; 10(82): 1924919254.

Natarajan, K. Panchgavya: a manual 1st (Edn.), pp: 2003;1-4.

Natt, M.P. and Herrick, C.A. A new blood diluent for counting erythrocytes and leucocytes of the chicken. Poultry Science. 1952; 31: 735-738.

Ritchie, B. W., Harrison, J. G. and Harrison, R. L. Avian Medicine, Winger's Publishing, Inc, Florida, 1994.

Sarkar, C.K., Mostofa, M., Sikder, M.M.H., Ansari, W.K., Ahamed, M.M., Parvej, M.S. and Hasan, M.R. Efficacy of kalo jeera seeds (Nigella sativa) and

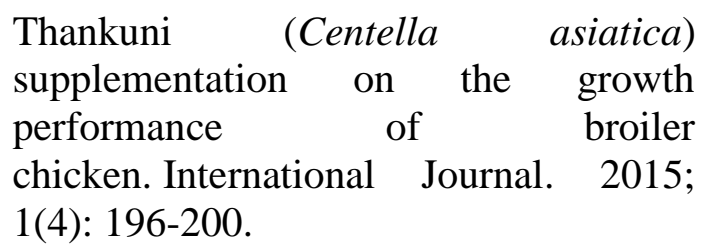

Sinha, S.N. and Biswas, M. Effect of extracts from Asparagus racemosus wild root against pathogenic bacteria. International Journal of Applied Biology and Pharmaceutical Technology. 2011; 2(3): 312-314.

Snedecor, G.W. and Cochran, W.G. Statistical Methods. Publ., Oxford and IBH publishing Co. New Delhi 1994; 4: 445446.

Sohalm, O.W., Jain, N.C. and Carroll, E.J. Veterinary Hematology, 3rd (Edn.) Lea and Febiger, Philadelphia. 1975; 18: 471-538.

Wray, C. and Davies, RH. Competitive exclusion-an alternative to antibiotics. Veterinary Journal. 2000; 59: 107-108.

\section{How to cite this article:}

Kamal Kishor, Y. P. Sahni, R. P. Singh, N. S. Meena and Rituraj Kewat. 2020. Effect of Different Fortifications of Panchgavya with Nigella sativa and Asparagus racemosus on Haematological Parameters in Poultry. Int.J.Curr.Microbiol.App.Sci. 9(10): 2092-2100. doi: https://doi.org/10.20546/ijcmas.2020.910.254 